\title{
Review on self-regulated learning in smart learning environment
}

\author{
Yusufu Gambo* (D) and Muhammad Zeeshan Shakir
}

\author{
* Correspondence: b00320837@ \\ studentmail.uws.ac.uk \\ School of Computing, Engineering \\ and Physical Sciences, University of \\ the West of Scotland, Paisley PA1 \\ $2 \mathrm{BE}, \mathrm{UK}$
}

\begin{abstract}
Despite the increasing use of the self-regulated learning process in the smart learning environment, understanding the concepts from a theoretical perspective and empirical evidence are limited. This study used a systematic review to explore models, design tools, support approaches, and empirical research on the selfregulated learning process in the smart learning environment. This review revealed that there is an increasing body of literature from 2012 to 2020. The analysis shows that self-regulated learning is a critical factor influencing a smart learning environment's learning process. The self-regulated learning components, including motivation, cognitive, metacognitive, self-efficiency, and metacognitive components, are most cited in the literature. Furthermore, self-regulated strategies such as goal setting, helping-seeking, time management, and self-evaluation have been founded to be frequently supported in the literature. Besides, limited theoretical models are designed to support the self-regulated learning process in a smart learning environment. Furthermore, most evaluations of the self-regulated learning process in smart learning environment are quantitative methods with limited mixed methods. The design tools such as visualization, learning agent, social comparison, and recommendation are frequently used to motivate students' learning engagement and performance. Finally, the paper presents our conclusion and future directions supporting the self-regulated learning process in the smart learning environment.
\end{abstract}

Keywords: Self-regulated learning process, Model, Smart learning environment, Smart learning, Learning strategies

\section{Introduction}

A smart learning environment is an emerging learning environment that integrates learning objects using smart and mobile technologies to provide smart learning processes for active learning experiences (Muthupoltotage \& Gardner, 2017; Zhu et al., 2016). It creates innovative approaches to smart learning, technological services to local on-campus and online students, easy local and remote student-to-faculty interactions and local and remote student-to-student collaborations (Hoel \& Mason, 2017). The emergence of a smart learning environment as a rapidly growing area represents how learning objects, learning processes, and learning activities are interrelated that can provide personalized and inclusive learning experiences (Zhu et al., 2016; Zhu \& He, 2012). A smart learning environment can be developed using smart and mobile

(c) The Author(s). 2021 Open Access This article is licensed under a Creative Commons Attribution 4.0 International License, which permits use, sharing, adaptation, distribution and reproduction in any medium or format, as long as you give appropriate credit to the original author(s) and the source, provide a link to the Creative Commons licence, and indicate if changes were made. The images or other third party material in this article are included in the article's Creative Commons licence, unless indicated otherwise in a credit line to the material. If material is not included in the article's Creative Commons licence and your intended use is not permitted by statutory regulation or exceeds the permitted use, you will need to obtain permission directly from the copyright holder. To view a copy of this licence, visit http://creativecommons.org/licenses/by/4.0/. 
technologies to bring learning personalization to meet learners' learning styles and needs (Singh \& Miah, 2020; Uskov et al., 2017). It brings a paradigm shift from traditional learning approaches to new learning methods and offers a student-centred learning environment that integrates diverse pedagogical methods and strategies to practice and reflect on the learning process; and take in a formal and informal learning situation (Singh \& Miah, 2020).

On the other hand, self-regulated learning (SRL) has been a critical factor affecting students' learning process (Dabbagh \& Kitsantas, 2004). The smart learning environment is a responsive, proactive, and context-aware learning environment. Therefore, it is of interest to explore how SRL can support a learner to develop thinking strategies and promotes metacognitive and motivations towards achieving learning goals (PérezÁlvarez et al., 2018; Durán-Sánchez et al., 2018; John et al., 2015; Zimmerman, 2002). The student's ability to control their learning process can enhance the educational process and provide the support needed to succeed in an online learning environment (Pérez-Álvarez et al., 2018; Spector, 2016; Zimmerman, 2002). How to support learners' SRL in online learning has been widely examined (Pérez-Álvarez et al., 2018; John et al., 2015). However, a smart learning environment as a new approach to online learning integrates many technologies and offered smart learning to meet learners' needs and learning style. Therefore, there is a need to explore how a smart learning environment supports SRL to inform future research directions. The findings of recent works (e.g., Pérez-Álvarez et al., 2018; Durán-Sánchez et al., 2018) show that different tools, designs, and evaluations have been used to support and evaluate the SRL process in an online learning environment. However, the findings are limited in scope, both in theory and empirical evidence on students' learning performance, achievements, retention, etc. Furthermore, there is a lack of well-documented review of SRL in a smart learning environment. The purposes of this paper are to systematically explore, analyze and report on the recent research of SRL in a smart learning environment to inform future research directions.

\section{Background}

Self-regulated learning is a self-thought, plan, and action cyclically used to achieve a learning goal (John et al., 2015; Zimmerman, 2002). It has been identified as one of the critical factors affecting students' success in a learning process (Dabbagh \& Kitsantas, 2004). SRL has models such as Zimmerman (1989), Pintrich (2000), Boekaert (1988), Winne and Hadwin (1998), Efklides (2011), etc., developed from different theoretical perspectives (Panadero, 2017). However, most of the models agreed to be cyclical and categorized the learning process into three phases, i.e., forethought, performance, and self-evaluation (Nussbaumer et al., 2015; Panadero, 2017).

Research works have shown that a smart learning environment can support students' SRL process (Pérez-Álvarez et al., 2018; Singh \& Miah, 2020). This learning process implies that learners become active and reflective of their learning process, and it requires both will and skills from the learners to succeed (Gavriushenko et al., 2017). One of the reasons for the interest in SRL is the increasing development of online skill-based courses both in the formal and informal learning process (John et al., 2015; Zimmerman, 2015; Schwendimann et al. 2016), which provided an opportunity for developing skills needed to live and function in society. SRL has some common components: 
cognitive, metacognitive, and motivation (Lee et al., 2019; Zimmerman, 2002). Cognitive ability refers to conscious mental activities and include thinking, reasoning, understanding, learning, and remembering (Verbert et al., 2014); the metacognitive is the ability to become aware of ones' awareness or the processes used to plan, monitor, and assess one's understanding and performance; and while the motivation is a perception of being self-competent, efficacious and autonomous (Gambo \& Shakir, 2021; John et al., 2015; Zimmerman, 2015). Zimmerman (2002) opined that SRL occurs with the interaction of the learning environment and learner. The learner can learn by observing and interacting with parents, teachers, peers, and those who demonstrate these behaviors (Pérez-Álvarez et al., 2018). The SRL strategies such as "self-efficacy, goal setting, time management, task strategy, and learning strategies and self-evaluation" are useful among literature in studying the SRL process (Pérez-Álvarez et al., 2018).

\section{Methods}

Procedure

This paper was conducted based on a systematic review that followed the procedure proposed by Petticrew and Roberts (2008). Systematic reviews are "a set of scientific methods that explicitly aim to limit systematic error (bias), mainly by attempting to identify, appraise and synthesize all relevant studies to answer a particular question (or set of questions)" (Petticrew \& Roberts, 2008, p. 9). This study followed the seven stages of Petticrew and Roberts' (2008) which includes: "defining the research questions or the hypothesis, determining the types of studies, conducting a comprehensive literature search, screening the search results, appraising the included studies, synthesizing the studies and assessing heterogeneity among the studies." Also, including reviewing references and citations in the systematic review (Greenhalgh \& Peacock, 2005).

Thus, the first stage is the research questions which are drawn from a systematic review of literature on SRL and online learning environment:

RQ1. What implementation strategies have been used to support SRL in a smart learning environment?

RQ2. What SRL strategies and components have been supported in a smart learning environment?

RQ3. What design functionalities have been used for supporting SRL strategies in a smart learning environment?

RQ4. How the implementations of the SRL process in a smart learning environment evaluated?

RQ5. What are the impacts of the SRL process in smart learning on students' learning process?

\section{Search criteria}

The second stage was to established criteria to determine related studies. The search articles defined as articles written in English and published in peer-reviewed journals or conference proceedings that proposed, implemented, or evaluated the SRL process in a smart learning environment, and focus on quality, practicality, and accessibility; and limited between 2012 and 2020 based on the fact that smart learning environment 
officially commences and published work began in 2012 (Putra \& Putro, 2019). Finally, the inclusion and exclusion criteria were defined to screen and select relevant articles. Table 1 shows the inclusion and exclusion criteria as defined for this review.

\section{Conducting search}

The third stage is conducting a comprehensive search in relevant databases using search terms. Several databases and search terms were chosen for the searching process. The search terms were adopted from the previous systematic review on SRL in online learning environments, smart learning environment and smart learning (PérezÁlvarez et al., 2018; Durán-Sánchez et al., 2018; Pérez-Álvarez et al., 2018). In addition, the searched process was conducted in ACM Digital Library, Scopus, IEEE Xplorer, Springer, Science Direct, and Google scholar to track other related articles are adopted from Pérez-Âlvarez et al. (2018).

The first strategy in searching the relevant articles are using "self-regulated learning AND smart learning environment". The second strategy in searching the articles is the combination of related terms as stated in search terms in Table 2. A total of 35 search terms were used following Boolean expression (A1 OR A2 OR A3 ... OR A25) AND (B1 OR B2 ... B10). The asterisk was used in the search terms to expand a search by discovering a combination of words that begin with the same letters and incomplete search terms used for the searching process.

\section{Screening process}

The screening processes involves stages four to seven, including reviewing references and citations in the systematic review (Greenhalgh \& Peacock, 2005), which are described as follows:

The search query resulted in 1117 related articles, and these resulted in 85 in ACM, 248 in IEEE, 243 in Scopus, 267 in Springer, 210 in science Direct, 64 in Google scholar.

By applying the fourth stage, which involved a screening search result based on the inclusion and exclusion criteria in Table 1, a total of 64 articles remained.

Table 1 Inclusion and Exclusion Criteria

\begin{tabular}{|c|c|}
\hline Inclusion Criteria & Exclusion Criteria \\
\hline $\begin{array}{l}\text { Empirical studies exploring SRL in smart education } \\
\text { environment }\end{array}$ & $\begin{array}{l}\text { Empirical studies exploring SRL outside smart } \\
\text { learning environment }\end{array}$ \\
\hline $\begin{array}{l}\text { Empirical studies exploring SRL in partially smart } \\
\text { education environment }\end{array}$ & $\begin{array}{l}\text { Articles that present the same subcomponents of } \\
\text { SRL but were grounded in other theories }\end{array}$ \\
\hline $\begin{array}{l}\text { Empirical studies that used SRL as theoretical model or } \\
\text { framework }\end{array}$ & Articles that provide only abstract \\
\hline Empirical studies that apply components of SRL & Articles that are presentation material \\
\hline $\begin{array}{l}\text { Publications that represent subcomponents of SRL based } \\
\text { on the SRL theory }\end{array}$ & Articles that don't offer results of a study \\
\hline Articles that provide results & Duplicate report of the same study \\
\hline $\begin{array}{l}\text { Articles developed models or design tools or support for } \\
\text { smart learning environment inclusive criteria }\end{array}$ & $\begin{array}{l}\text { Social network learning } \\
\text { Online portfolio }\end{array}$ \\
\hline $\begin{array}{l}\text { Approved manuscripts which meet the above inclusive } \\
\text { criteria in peer review journal or conference proceedings }\end{array}$ & $\begin{array}{l}\text { Approved manuscripts which meet the above } \\
\text { exclusive criteria }\end{array}$ \\
\hline
\end{tabular}


Table 2 Search terms*

\begin{tabular}{ll}
\hline A1. Self-regulat* learning & B1. Smart education environment \\
A2. Metacog* & B2. Smart education system \\
A3. Learning skills & B3. Mobile learning \\
A4. Rehearsal & B4. Smart learning \\
A5. Elaboration & B5. Smart web-based learning \\
A6. Critical thinking & B6. Smart learning environment \\
A7. Monitoring & B7. Smart loT-based learning \\
A8. Time management & B8. Intelligence learning environment \\
A9. Effort regulation & B9. Smart learning \\
A10. Self-directed learning & B10. Smart education \\
A11. Help-seeking & \\
A12. Goal setting & \\
A13. Environment structur* & \\
A14. Self-efficiency & \\
A15. Task value & \\
A16. Planning & \\
A17. Task strategy & \\
A18. Intrinsic goal orientation & \\
A19. Extrinsic goal orientation & \\
A20. Control belief & \\
A21. Test anxiety & \\
A22. Task interest & \\
A23. Outcomes expectation & \\
A24. Self-consequence & \\
A25. Self-evaluation & \\
\hline
\end{tabular}

We further applied stage five, which is appraising the included articles based on the titles, abstracts, keywords, and applied inclusion criteria; a total of 37 remained.

We synthesized the articles (stage six) and assessed heterogeneity (stage seven); a total of 18 articles remained, and then applied the snowball method (Greenhalgh \& Peacock, 2005) to the reference lists of the 18 articles by scanning their citations through Google scholar databases, and three more duplicate articles were removed. Finally, 15 articles are deemed to support SRL in a smart learning environment.

The combined searching and screening processes are shown in Fig. 1. Table 3 shows the search results of the 15 articles deemed relevant to address the research questions.

\section{Result and discussions}

Based on the research questions defined, the contents of the 15 articles presented in Table 3 were analyzed. The results and discussion were presented below:

RQ1: What implementation strategies have been used to support SRL in a smart learning environment?

In analyzing the articles to support the SRL process in Tables 3, 11 tools are implemented to provide intervention, and 4 proposed design models to support SRL. Among the 11 tools implemented to support SRL, 9 tools were implemented as a web-based application, while 3 are mobile apps. This study is consistent with Pérez-Álvarez et al. 


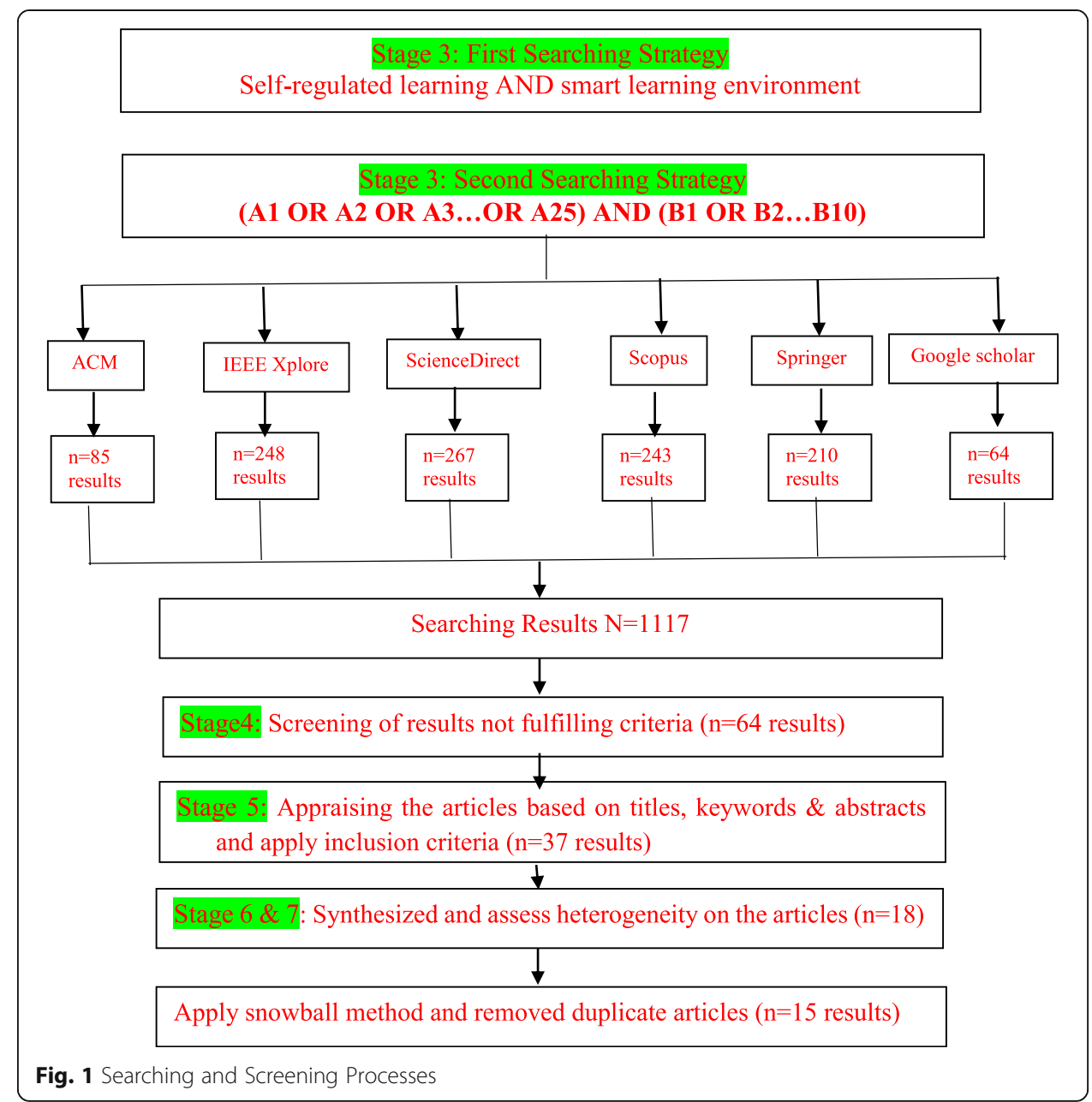

(2018), who found that the SRL strategies have been supported in a smart learning environment to provide skills development and personalized learning experiences.

RQ2: What SRL strategies and components have been supported in a smart learning environment?

In analyzing the tools developed to support SRL strategies, we identified 6 SRL strategies that are frequently supported in a smart learning environment as follows:

- Goal setting: This strategy appears in 11 implementations, that is, those developed smart learning environments that provided a mechanism for selecting or defining goals to developed skills, improve performance, or defining activities to be achieved in a learning process.

- Task Strategy: This strategy appears in 7 implementations. Those developed a smart learning environment to provide a mechanism for planning activities before performing on them.

- Help-seeking: They are supported in 6 implementations; these were implemented through agents and forums.

- Time Management: The strategy appears in 7 implementations. These developed a smart learning environment to monitor the time spent on learning, assessment, or planning. 
Table 3 Search Results

\begin{tabular}{|c|c|c|c|c|}
\hline Reference & Description of Application & Evaluation Method & $\begin{array}{l}\text { SRL } \\
\text { Evaluated }\end{array}$ & $\begin{array}{l}\text { Design } \\
\text { Functionalities }\end{array}$ \\
\hline $\begin{array}{l}\text { Akinyi and } \\
\text { Oboko } \\
(2020)\end{array}$ & $\begin{array}{l}\text { Proposed Self-regulated col- } \\
\text { laborative learning model } \\
\text { based on social cognitive } \\
\text { theory }\end{array}$ & $\begin{array}{l}\text { Proposed model for } \\
\text { reducing dropout in an } \\
\text { eLearning environment }\end{array}$ & $\begin{array}{l}\text { General self- } \\
\text { regulated learn- } \\
\text { ing process }\end{array}$ & Collaboration \\
\hline $\begin{array}{l}\text { Manganello } \\
\text { et al. (2019) }\end{array}$ & $\begin{array}{l}\text { Examined the effect of SRL- } \\
\text { based web platform }\end{array}$ & $\begin{array}{l}\text { The mixed-method used } \\
\text { to evaluate active engage- } \\
\text { ment among students }\end{array}$ & $\begin{array}{l}\text { SRL strategies in } \\
\text { web-learning } \\
\text { platform }\end{array}$ & $\begin{array}{l}\text { Learning } \\
\text { engagement }\end{array}$ \\
\hline $\begin{array}{l}\text { Bahreman } \\
\text { et al. (2016) }\end{array}$ & $\begin{array}{l}\text { The system used SRL-based } \\
\text { achievements in the educa- } \\
\text { tional mobile app to motiv- } \\
\text { ate students to learn and } \\
\text { practice with the mobile } \\
\text { learning environment. }\end{array}$ & $\begin{array}{l}\text { Used survey to measure } \\
\text { the impacts of the mobile } \\
\text { environment on learning } \\
\text { engagement and learning } \\
\text { outcome of a student. The } \\
\text { result showed an increase } \\
\text { in engagement and } \\
\text { outcomes }\end{array}$ & $\begin{array}{l}\text { Cognition, } \\
\text { Metacognition, } \\
\text { Motivational/ } \\
\text { Affective }\end{array}$ & Feedback \\
\hline $\begin{array}{l}\text { Chatzara } \\
\text { et al. (2016) }\end{array}$ & $\begin{array}{l}\text { The system incorporated an } \\
\text { agent called Sophia to help } \\
\text { a student in the learning } \\
\text { process and foster cognitive } \\
\text { learning in disabled student }\end{array}$ & $\begin{array}{l}\text { Used survey to measure } \\
\text { students' learning } \\
\text { performance. The results } \\
\text { show an increase in the } \\
\text { components measured. }\end{array}$ & $\begin{array}{l}\text { Affective/ } \\
\text { Motivational }\end{array}$ & Feedback \\
\hline $\begin{array}{l}\text { John et al. } \\
\text { (2015) }\end{array}$ & $\begin{array}{l}\text { SIMSELF was used an Open- } \\
\text { ended computer-based } \\
\text { learning environments sys- } \\
\text { tem to support SRL. }\end{array}$ & $\begin{array}{l}\text { Pretest and posttest using. } \\
\text { The result shows that } \\
\text { students who used the } \\
\text { facilities in the learning } \\
\text { platform increased in a } \\
\text { performance that does } \\
\text { who didn't use it. }\end{array}$ & $\begin{array}{l}\text { SRL strategies: } \\
\text { Planning, } \\
\text { performance, } \\
\text { monitoring, and } \\
\text { reflection. }\end{array}$ & $\begin{array}{l}\text { Visualization, Class } \\
\text { comparison, } \\
\text { Feedback }\end{array}$ \\
\hline $\begin{array}{l}\text { Manso- } \\
\text { Vázquez } \\
\text { et al. (2015) }\end{array}$ & $\begin{array}{l}\text { The system used Tin Can API } \\
\text { to track learners' learning } \\
\text { activities to support them in } \\
\text { an eLearning environment }\end{array}$ & $\begin{array}{l}\text { The implementation is } \\
\text { needed to be validated }\end{array}$ & $\begin{array}{l}\text { General SRL } \\
\text { process }\end{array}$ & Visualization \\
\hline $\begin{array}{l}\text { Nussbaumer } \\
\text { et al. (2015) }\end{array}$ & $\begin{array}{l}\text { The study introduced } \\
\text { Psycho-Pedagogical- frame- } \\
\text { work to find out if students } \\
\text { were able to follow a self- } \\
\text { regulated process }\end{array}$ & $\begin{array}{l}\text { Used survey to evaluate } \\
\text { the impacted on students' } \\
\text { SRL. The result show } \\
\text { students can followed the } \\
\text { process and improved } \\
\text { learning experiences }\end{array}$ & $\begin{array}{l}\text { Cognitive, } \\
\text { Metacognitive, } \\
\text { Motivations/ } \\
\text { affective }\end{array}$ & Visualization \\
\hline $\begin{array}{l}\text { Koorsse et al. } \\
\text { (2014) }\end{array}$ & $\begin{array}{l}\text { This system introduced } \\
\text { formative assessments into } \\
\text { the mobile learning } \\
\text { environment to motivate } \\
\text { students to practice and do } \\
\text { more exercises. }\end{array}$ & $\begin{array}{l}\text { Used survey to determine } \\
\text { how the mobile } \\
\text { environment motivated } \\
\text { students learning and } \\
\text { performance which } \\
\text { received positive feedback } \\
\text { and increased } \\
\text { performances }\end{array}$ & $\begin{array}{l}\text { Motivation/ } \\
\text { Affective }\end{array}$ & Visualization \\
\hline $\begin{array}{l}\text { Nussbaumer } \\
\text { et al. (2014) }\end{array}$ & $\begin{array}{l}\text { The aimed of the system is } \\
\text { to use Responsive And open } \\
\text { learning environment to } \\
\text { support students' SRL } \\
\text { process. }\end{array}$ & $\begin{array}{l}\text { Used multi-survey study to } \\
\text { examine how teachers } \\
\text { and students used the en- } \\
\text { vironment in terms of ac- } \\
\text { ceptability, usefulness and } \\
\text { factors influencing the use } \\
\text { of the widgets for learning } \\
\text { which provide useful } \\
\text { insight into improve the } \\
\text { design. }\end{array}$ & $\begin{array}{l}\text { SRL phases using } \\
\text { the } \\
\text { Responsive and } \\
\text { open learning } \\
\text { environment }\end{array}$ & $\begin{array}{l}\text { Visualization, } \\
\text { Recommendation }\end{array}$ \\
\hline $\begin{array}{l}\text { Tu et al. } \\
\text { (2012) }\end{array}$ & $\begin{array}{l}\text { The system incorporated } \\
\text { Web technologies to } \\
\text { determine if the } \\
\text { environment can support } \\
\text { learners' SRL. }\end{array}$ & $\begin{array}{l}\text { Used online survey to } \\
\text { evaluate show positive } \\
\text { responses from the } \\
\text { participants }\end{array}$ & $\begin{array}{l}\text { General SRL } \\
\text { strategies: } \\
\text { Goal setting, } \\
\text { time } \\
\text { management, } \\
\text { and task } \\
\text { strategies }\end{array}$ & $\begin{array}{l}\text { Visualization, } \\
\text { Feedback, } \\
\text { Collaboration, } \\
\text { Recommendation }\end{array}$ \\
\hline
\end{tabular}


Table 3 Search Results (Continued)

\begin{tabular}{|c|c|c|c|c|}
\hline Reference & Description of Application & Evaluation Method & $\begin{array}{l}\text { SRL } \\
\text { Evaluated }\end{array}$ & $\begin{array}{l}\text { Design } \\
\text { Functionalities }\end{array}$ \\
\hline $\begin{array}{l}\text { Lehmann } \\
\text { et al. (2013) }\end{array}$ & $\begin{array}{l}\text { The system } \\
\text { Introduced prompt in self- } \\
\text { regulated online learning en- } \\
\text { vironment to promote } \\
\text { personalization and } \\
\text { adaptation }\end{array}$ & $\begin{array}{l}\text { Used survey to determine } \\
\text { the usefulness of the } \\
\text { prompts to support online } \\
\text { personalization and } \\
\text { adaptation }\end{array}$ & \begin{tabular}{l} 
Metacognitive \\
awareness, \\
Motivation\} $\\
{\text { Affective, }} \\
{\text { Cognitive }}$ & Interactivity \\
\hline $\begin{array}{l}\text { Lajoie et al. } \\
\text { (2013) }\end{array}$ & $\begin{array}{l}\text { This system introduced a } \\
\text { BioWorld } \\
\text { system to help the medical } \\
\text { students receive feedback } \\
\text { form experts while solving } \\
\text { authentic patients' cases. }\end{array}$ & $\begin{array}{l}\text { Used survey to conduct } \\
\text { three studies which } \\
\text { revealed that medical } \\
\text { Student increase in the } \\
\text { learning process in terms } \\
\text { of diagnosis and accuracy } \\
\text { in solving patient cases }\end{array}$ & Metacognitive & $\begin{array}{l}\text { Visualization, } \\
\text { Feedback, } \\
\text { Recommendation, } \\
\text { Collaboration }\end{array}$ \\
\hline $\begin{array}{l}\text { Winne \& } \\
\text { Hadwin } \\
\text { (2013) }\end{array}$ & $\begin{array}{l}\text { The system introduced a } \\
\text { learning platform called } \\
\text { nStudy to help new medical } \\
\text { students and experts } \\
\text { interacts during learning and } \\
\text { diagnosing patients' cases }\end{array}$ & $\begin{array}{l}\text { Used survey to evaluate } \\
\text { trace of data and learning } \\
\text { behaviors which show } \\
\text { that learners have } \\
\text { improved in the learning } \\
\text { process }\end{array}$ & $\begin{array}{l}\text { Cognitive, } \\
\text { Metacognitive }\end{array}$ & $\begin{array}{l}\text { Visualization, } \\
\text { Feedback, } \\
\text { Recommendation, } \\
\text { Collaboration }\end{array}$ \\
\hline $\begin{array}{l}\text { Canțer } \\
\text { (2013) }\end{array}$ & $\begin{array}{l}\text { The system introduced a } \\
\text { hybrid model of an e- } \\
\text { learning system called MEM } \\
\text { (Metacognitive e-learning } \\
\text { model) to improve students' } \\
\text { metacognitive skills }\end{array}$ & Proposed model & $\begin{array}{l}\text { A model to } \\
\text { measure } \\
\text { metacognitive } \\
\text { skills }\end{array}$ & Proposed design \\
\hline $\begin{array}{l}\text { Sahabudin } \\
\text { and Ali } \\
\text { (2012) }\end{array}$ & $\begin{array}{l}\text { This system combined Self- } \\
\text { regulated Learning and Per- } \\
\text { sonalized Learning (SRPL) to } \\
\text { propose a personalized } \\
\text { learning environment to sup- } \\
\text { port the learning environ- } \\
\text { ments' SRL process. }\end{array}$ & $\begin{array}{l}\text { A proposed personalized } \\
\text { learning environment }\end{array}$ & $\begin{array}{l}\text { General self } \\
\text { Regulated } \\
\text { Learning } \\
\text { phases. }\end{array}$ & $\begin{array}{l}\text { Proposed design } \\
\text { Process }\end{array}$ \\
\hline
\end{tabular}
\end{tabular}

- Monitoring: This appears in 10 implementations. This is a significant component of the SRL process. This strategy provides a mechanism to see if a student is moving towards achieving a set goal.

- Self-evaluation: This is presented in 11 implementations. This can either provide an evaluation of learners' activities or progress of learning progress.

In analyzing the tools developed to support specific SRL components, we identified 4 related SRL components that are frequently supported as follows:

- Affective/Motivational: Both of the components are emotion and are measured at the self-evaluation phase of the SR. They are supported in 5 implementations; these were implemented through self-assessment, games, and reflective quizzes.

- Cognition: The component appears in 4 implementations. These developed to monitor and measure time spent on learning, assessment, or planning.

- Metacognition: This appears in 6 implementations. This is a significant component of the SRL process. This strategy provides a mechanism to monitor learning and achieving a set goal.

The implemented strategies developed to support SRL strategies and components in a smart learning environment highlighted three strategies and components. The goal is the most supported strategy, while help-seeking is the least support. Metacognition is the most supported literature, followed by cognition and affective/motivation on the 
SRL components. This is consistent with most literature supporting SRL strategies and components and their importance in helping learners achieve a learning goal (Bahreman et al., 2016; Koorsse et al., 2014; Panadero, 2017).

RQ3: What design functionalities have been used for supporting SRL strategies in a smart learning environment?

The analysis of the design functionalities considered for supporting SRL is presented. We followed the categories defined by Bodily and Verbert (2017) to categorize features of the design tools used to support the SRL process.

- Visualization: 10 used visualization to support self-regulation learning strategies. This show student can use a progress bar or chat to see the learning process's progress and outcomes.

- Class comparison: 3 used the comparison to support the SRL process. This tool provides a mechanism to compare learner's performance with their classmates.

- Feedback: 8 used textual feedback to support self-regulated learning using solutions to the current problem, personalized messages, or correction.

- Recommendation: 5 of the tools reported to the used recommendation to support self-regulated learning. The recommendation can be skill-based, strategies or widgets to help learners' skills development

- Collaboration: 5 integrated collaboration tool that supports learners' help-seeking. These include discussion forums, learning agents, or peer learning.

- Interactivity: 2 used interactivity tools to resend the information to the learners about their learning progress and performances.

The findings found both action-related and content-related as the most frequently used literature to support the SRL process in a smart learning environment.

RQ4: How the implementations of the SRL process in a smart learning environment evaluated?

In analyzing the tools or applications implemented to support self-regulated learning, 11 tools or applications were assessed to measure the impact on self-regulated learning overlapping different measurements. The evaluations indicated the following approaches:

- Usability: The analysis shows that 7 evaluated the usability of the functionalities provided. This measures the learner's opinion on whether the functionalities provided are ease to use and meet their learning need.

- Usefulness: The analysis shows that 4 evaluated the usefulness of the functionalities provided. This measure degree of importance to the learning process.

- Acceptability: The analysis shows that 2 evaluated learners' acceptability of the functionalities. This measures the degree of quality to the functionalities provided to support their learning process.

- Satisfaction: The analysis shows that 3 evaluated learner satisfaction. This is the degree to how the functionalities meet learner's learning needs and expectations.

The findings show that usability and usefulness are most frequently used to evaluate the self-regulated learning process in a smart learning environment. Usability is one of 
the keys to learning satisfaction, and thus a smart learning environment needs to useful and satisfied a learner for a sustainable learning performance (Pérez-Álvarez et al., 2018; Schwendimann et al., 2016).

RQ5. What are the impacts of the SRL process in smart learning on students' learning?

In analyzing the impacts of the self-regulated learning process in a smart learning. environment on student' learning, several metrics are used and overlapping for effective.

evaluation. These measures are:

- Learning achievements: This is how the system brought a relative change in knowledge and understanding. The analysis shows that 9 evaluated learning performance.

- Learning difficulty and disorder: This is the degree to how learning intervention supported learning difficulties among students. This analysis shows that 1 evaluated learning difficulty.

- Learning progress: This is the degree to which the learning intervention supported learning skills and domain knowledge. This analysis shows that 4 evaluated learning progress.

- Learning personalization: This is how learning intervention provides learning content based on the learner's needs, skills, strength, and interest. The analysis shows that 3 of the intervention evaluated learning personalization to support learning achievements.

The findings show that learning achievements have been frequently evaluated. The essence of the self-regulated learning process in a smart learning environment is to provide support through learning personalization and skills development for learner's learning achievements and progress (Pérez-Álvarez et al., 2018). A study on selfregulated learning in a smart learning the environment is only beneficial for educators to the degree that they demonstrate how the findings link their approaches to real learning outcomes, and this has been demonstrated in this review.

\section{Lessons learned}

This paper conducted a systematic literature analysis to understand how a smart learning environment supported the self-regulated learning process. The analysis results identified results that could help future self-regulated learning strategies in a smart learning environment.

Several tools were developed and implemented to support the SRL process without a definite model or framework to understand their pedagogical theory. Providing a theory to support the design and development of a smart learning system provides a lens through which the learning environment can support the learning process and provide insights into key performance indicators.

Several SRL components have been supported in the literature, i.e., cognitive, metacognitive, affective/ motivation. The metacognitive elements appear to have been supported most based on the analysis. Furthermore, goal setting, time management, and 
help-seeking are the most frequent strategies that influenced learners' metacognitive skills. However, little is known about how the smart learning system can be modelled to support metacognitive strategy and whether these strategies can be implemented in a smart learning environment to support the self-regulated learning process.

The design functionalities used different tools to support learners' SRL process in a smart learning environment. Visualization, feedback, recommendation, and collaboration are standard design tools for supporting learner's SRL. The result shows that visualization is the most frequent design functionalities used, influencing learners' motivation and engagement. Furthermore, feedback on learners' learning process has been positive, influencing learners' engagement in a smart learning environment for supporting the SRL process.

Several SRL models are used in literature to understand how they can support the learning process in a smart learning environment; however, both Zimmerman and Pintrich models are frequently used to implement the SRL process in a smart learning environment. The Zimmerman has model has been the most frequently used in literature.

Several approaches and metrics have been used to measure the self-regulated learning process's impacts in a smart learning environment. However, learning achievements have been frequently used, which demonstrated the intervention's essence is to link the impact on achievements.

Most of the studies are quantitative in evaluation methods, using a survey in a smallscale sample population with some closed-ended questions with limited samples, leading to limited outcomes. The smart learning system is an emerging learning concept seeking to establish its domain. Therefore, developing qualitative studies or mixed will provide a better understanding of the user experiences to provide insight into the reviews to guide implementation initiatives and theory development. Furthermore, most of the studies lack theory to underpin the evaluation methods. Using theories will provide a lens for the interpretation and validity of the evaluation results and increase confidence in generalizing findings.

\section{Conclusion}

This systematic analysis provided insights into the current state of the SRL process in a smart learning environment. This study revealed that SRL research in a smart learning environment had evolved increasingly, as demonstrated by the fact that papers were reviewed between 2012 and 2020. The result indicated that SRL strategies such as goalsetting, helping-seeking, time management, and self-evaluation are mostly supported. However, most evaluation studies lack theoretical models, which undermined the validity of the evaluation results. Using models will provide a lens through which the interpretations of the results can be validated.

Moreover, using a theoretical framework in a study gives the researcher the process to conceptualize the study in a broader context. Furthermore, we also found that most of the evaluation studies are quantitative, smart learning system as a new learning paradigm is seeking to establish its domain; therefore, there is a need to use both quantitative and qualitative to provide an in-depth understanding of the experiences of a user in the self-regulated learning environment. We also found that learning agent, visualization, recommendation, interactive, and social comparison positively impact the students' engagement and performance, which can support a self-regulated learning 
paradigm. Furthermore, most of the studies measured usefulness and usability; there is a need to explore beyond these functionalities to explore how SRL strategies are affected within the learning environment with real users. We also found a scarcity of intelligent systems to support the design of tools or applications for self-regulated learning processes. There is a lack of a design approach to guide a self-regulated smart education system design. Besides, it was observed that different interventions, such as visualization, feedback, recommendation, etc., are used to support learners' learning process. The results of this review may have possible new perspectives and guidance for future smart learning environment research. This research will also provide smart learning environment practitioners with the knowledge and the significance of promoting SRLs in a smart learning environment.

There are limitations to understand the consequences of this systematic analysis. First, as the scanning time for discovering possible publications ended at a specific date, any papers written after that point will not have been identified in this study. Second, this analysis's scope is restricted to articles that focused on proposed studies, implemented and evaluated the SRL process in a smart learning environment. Based on these results, guidance for the future, researchers can continue to explore SRLs in smart learning environments to add to a growing body of literature. Third, other SRL methods that have not been examined in this analysis should be explored; the construction of recommendations for self-regulated learning in the smart learning context, the computational frameworks used to develop and evaluate SRLs in the smart learning environment called for future works.

Acknowledgements

The authors acknowledged Adamawa State University, Mubi-Nigeria, for sponsoring this research.

Authors' contributions

Yusufu Gambo has made substantial contributions to conceive and design the research. And searched and analyzed the literature. Muhammad Zeeshan Shakir has made significant contributions to draft this manuscript, improved the manuscript's language, and commented on the manuscripts. Yusufu Gambo reviewed and revised the manuscript into its final shape. The author(s) read and approved the final manuscript.

Funding

The Adamawa State University, Mubi-Nigeria, support this research work.

Availability of data and materials

Not applicable.

\section{Declarations}

Competing interests

They have no conflicts of interest to disclose and permit any reviewer to review our manuscript.

Received: 24 March 2021 Accepted: 4 July 2021

Published online: 18 July 2021

\section{References}

Akinyi, G. L., \& Oboko, R. (2020). Proposed self-regulation model for collaborative E-learning systems in Kenyan public universities. American Journal of Engineering and Applied Sciences, 13(1), 37-48. https://doi.org/10.3844/ajeassp.2020.37.48. Bahreman, V., Chang, M., Amistad, I., \& Garn, K. (2016). Design and implementation of self-regulated learning achievement: Attracting students to perform more practice with educational mobile apps. In State-of-the-art and future directions of smart learning, (pp. 263-267. http://maiga.athabascau.ca/publication/Conference-2015-ICSLE2015.pdf). Singapore: Springer. https://doi.org/10.1007/978-981-287-868-7_30.

Bodily, R., \& Verbert, K. (2017). Trends and issues in student-facing learning analytics reporting systems research, Proceedings of the seventh international learning analytics \& knowledge conference (pp. 309-318). https://doi.org/10.1145/3027385.30274 03.

Boekaerts, M. (1988). Motivated learning: Bias in appraisals. International Journal of Educational Research, 12, 267-280. https:// doi.org/10.1016/0883-0355(88)90005-5. 
Canțer, M. (2013). A hybrid model for an e-learning system which develops metacognitive skills in students. In International conference on human Interface and the Management of Information, (pp. 9-15). Berlin: Springer https://link.springer.com/ chapter/10.1007/978-3-642-39226-9_2.

Chatzara, K., Karagiannidis, C., \& Stamatis, D. (2016). Cognitive support embedded in self-regulated e-learning systems for students with special learning needs. Educ. Inf. Technol., 21(2), 283-299. https://doi.org/10.1007/s10639-014-9320-1.

Dabbagh, N., \& Kitsantas, A. (2004). Using learning management systems as metacognitive tools to support self-regulation in higher education contexts. In R. Azevedo, \& V. Aleven (Eds.), International handbook of metacognition and learning technologies, (pp. 197-121). New York: Springer. https://doi.org/10.1007/978-1-4419-5546-3_14.

Durán-sánchez, A., Alvarez-García, J., Río-rama, M., \& Sarango-lalangui, P. (2018). Analysis of the scientific literature published on smart learning. Revisit Education, 39(10), 7 http://www.revistaespacios.com/a18v39n10/18391007.html.

Efklides, A. (2011). Interactions of metacognition with motivation and affect in self-regulated learning: The MASRL model. Educational Psychologist, 46(1), 6-25. https://doi.org/10.1080/00461520.2011.538645.

Gambo, Y., \& Shakir, M. Z. (2021). WIP: Model of Self-Regulated Smart Learning Environment. In 2021 IEEE World Conference on Engineering Education (EDUNINE) (pp. 1-4). IEEE.

Gavriushenko, M., Lindberg, R. S., \& Khriyenko, O. (2017). Smart educational process based on personal learning capabilities. In EDULEARN17 proceedings. 9th international conference on education and new learning technologies, IATED academy. https:// doi.org/10.21125/edulearn.2017.2434.

Greenhalgh, T., \& Peacock, R. (2005). Effectiveness and efficiency of search methods in systematic reviews of complex evidence: Audit of primary sources. British Medical Journal, 331(7524), 1064-1065. https://doi.org/10.1136/bmj.38636.5934 61.68.

Hoel, T., \& Mason, J. (2017). Standards for smart education-towards a development framework. Smart Learning Environments, 5(1), 3. https://doi.org/10.1186/s40561-018-0052-3.

John, S., Kinnebrew, C., Gauch, R., \& Biswas, B. (2015). Studying student use of self-regulated learning tools in an open-ended learning environment, (vol. 9112, pp. 185-194). Switzerland: Springer International Publishing, AlED LNAl. https://doi.org/1 0.1007/978-3-319-19773-9.

Koorsse, M., Olivier, W., \& Greyling, J. (2014). Self-regulated mobile learning and assessment: An evaluation of assessment interfaces. Journal of information technology education: Innovations in practice, 13, 89-109 http://www.jite.org/documents/ Vol13/JITEv13IIPp089-109Koorsse0733.pdf.

Lajoie, S. P., Naismith, L., Poitras, E., Hong, Y.-J., Cruz-Panesso, I., Ranellucci, J., ... Wiseman, J. (2013). Technology-rich tools to support self-regulated learning and performance in medicine. In R. Azevedo, \& V. Aleven (Eds.), International handbook of metacognition and learning technologies, (pp. 229-242). New York: Springer. https://doi.org/10.1007/978-1-4419-5546-3_1 6.

Lee, D., Watson, S. L., \& Watson, W. (2019). Systematic literature review on self-regulated learning in massive open online courses. Australasian Journal of Educational Technology, 35(1), 1449-5554 http://orcid.org/0000-0003-1111-9691.

Lehmann, T., Hähnlein, I., \& Ifenthaler, D. (2013). Cognitive, metacognitive and motivational perspectives on pre-flection in self-regulated online learning. Computers in Human Behavior, 32, 313-323. https://doi.org/10.1016/j.chb.2013.07.051.

Manganello, C., Falsetti, C., \& Leo, T. (2019). Self-regulated learning for web-enhanced control engineering education. Educational Technology \& Society, 22(1), 44-58 https://eric.ed.gov/?id=EJ1202779.

Manso-Vázquez, M., Caeiro-Rodríguez, M., \& Llamas-Nistal, M. (2015). xAPI-SRL: Uses of an application profile for self-regulated learning based on the analysis of learning strategies. In IEEE Frontiers in education conference (FIE), (pp. 1-8). https://doi. org/10.1109/ACCESS.2018.2860519.

Muthupoltotage, U., \& Gardner, L. (2017). Undergraduates perception of informal personal learning environments: Affordances for self-regulated learning, (pp. 1-3). Hobart: Australasian Conference on Information Systems https://aisel.aisnet.org/acis201 $7 / 49$.

Nussbaumer, A., Hillemann, E., Gütl, C., \& Albert, D. (2015). A competence-based service for supporting self-regulated learning in virtual environments. Journal of Learning Analytics, 2(1), 101-133 https://files.eric.ed.gov/fulltext/EJ1126954.pdf.

Nussbaumer, A., Kravcik, M., Renzel, D., Klamma, R., Berthold, M., \& Albert, D. (2014). A framework for facilitating self-regulation in responsive open learning environments. Graz University of Technology https://graz.pure.elsevier.com/en/publications/aframework-for-facilitating-self-regulation-in-responsive-open.

Panadero, E. (2017). A review of self-regulated learning: Six models and four directions for research. Frontiers in psychology, 8 , 422 https://www.frontiersin.org/articles/10.3389/fpsyg.2017.00422/full.

Pérez-Álvarez, R., Maldonado-Mahauad, R., \& Pérez-Sanagustín, M. (2018). Tools to support self-regulated learning in online environments: Literature review. In European conference on technology enhanced learning (pp. 16-30). Springer, Cham. https://doi.org/10.1007/978-3-319-98572-5_2.

Petticrew, M., \& Roberts, H. (2008). Systematic reviews in the social sciences: A practical guide. Wiley.

Pintrich, P. R. (2000). The role of goal orientation in self-regulated learning. In M. Boekaerts, P. R. Pintrich, \& M. Zeidner (Eds.), Handbook of self-regulation, (pp. 452-502). San Diego: Academic Press http://cachescan.bcub.ro/e-book/E1/580704/451-52 9.pdf.

Putra, R. R. J., \& Putro, B. L. (2019). Smart education: Educational service system for equal quality education. In Journal of physics: Conference series (1280, 3, 032029). IOP Publishing. doi: https://doi.org/10.1088/1742-6596/1280/3/032029

Sahabudin, N. A., \& Ali, M. B. (2012). Combination of two learning approaches which are self-regulated learning and personalized learning (SRPL). In 2012 international conference on management and education innovation IPEDR, (p. 37) http://www.ipedr.com/vol37/036-ICMEl2012-E10012.pd.

Schwendimann, B. A., Rodriguez-Triana, M. J., Vozniuk, A., Prieto, L. P., Boroujeni, M. S., Holzer, A., \& Dillenbourg, P. (2016). Perceiving learning at a glance: A systematic literature review of learning dashboard research. IEEE Transactions on Learning Technologies, 10(1), 30-41.

Singh, H., \& Miah, S. J. (2020). Smart education literature: A theoretical analysis. Educ. Inf. Technol., 25(4), 3299-3328. https:// doi.org/10.1007/s10639-020-10116-4.

Spector, J. M. (2016). Smart learning environments: Concepts and issues. In G. Chamblee, \& L. Langub (Eds.), Proceedings of Society for Information Technology \& teacher education international conference, (pp. 2728-2737). Savannah: Association for the Advancement of computing in education (AACE) https://www.learntechlib.org/primary/p/172078/. 
Tu, Chih-Hsiung, Laura Sujo-Montes, Cherng-Jyh Yen, Junn-Yih Chan, and Michael Blocher. (2012). "The integration of personal learning environments \& open network learning environments." TechTrends 56(3), 13-19. https://www.glokalde. com/pdf/issues/7/Review-1.pdf.

Uskov, V. L., Bakken, J. P., Heinemann, C., Rachakonda, R., Guduru, V. S., Thomas, A. B., \& Bodduluri, D. P. (2017). Building smart learning analytics system for smart-university. In International conference on smart education and smart E-learning, (pp. 191-204). Cham: Springer. https://doi.org/10.1007/978-3-319-59451-4_19.

Verbert, K., Govaerts, S., Duval, E., Santos, J. L., Van Assche, F., Parra, G., \& Klerkx, J. (2014). Learning dashboards: An overview and future research opportunities. Personal and Ubiquitous Computing, 18(6), 1499-1514. https://doi.org/10.1007/s00779013-0751-2

Winne, P. H., \& Hadwin, A. F. (2013). nStudy: Tracing and supporting self-regulated learning in the Internet. In International handbook of metacognition and learning technologies (pp. 293-308). Springer, New York, NY.

Winne, P. H., \& Hadwin, A. F. (1998). Studying as self-regulated engagement in learning. In D. Hacker, J. Dunlosky, \& A Graesser (Eds.), Metacognition in educational theory and practice, (pp. 277-304). Hillsdale: Erlbaum http://www.sciepub. com/reference/85850.

Zhu, Z., Yu, M., \& Riezebos, P. (2016). A research framework of smart education. Smart Learning Environment, 3(1), 1-17. https://doi.org/10.1186/s40561-016-0026-2.

Zhu, Z. T., \& He, B. (2012). Smart education: New frontier of educational informatization. E-education Research, 12, 1-13.

Zimmerman, B. (2015). Self-regulated learning: Theories, measures, and outcomes. International Encyclopedia of the Social \& Behavioral Sciences, 541-546. https://doi.org/10.1016/B978-0-08-097086-8.26060-1.

Zimmerman, B. J. (1989). A social cognitive view of self-regulated academic learning. Journal of educational psychology, 81(3), 329.

Zimmerman, B. J. (2002). Becoming a self-regulated learner: An overview. Theory into Practice, 2(41), 64. https://doi.org/10.12 07/s15430421tip4102_2.

\section{Publisher's Note}

Springer Nature remains neutral with regard to jurisdictional claims in published maps and institutional affiliations.

\section{Submit your manuscript to a SpringerOpen ${ }^{\circ}$ journal and benefit from:}

- Convenient online submission

- Rigorous peer review

- Open access: articles freely available online

- High visibility within the field

- Retaining the copyright to your article

Submit your next manuscript at $\boldsymbol{\nabla}$ springeropen.com 